\title{
1 Trace element-mineral associations in modern and ancient iron terraces
}

2

3

4

5

6

7

8

9 10

11

12

13 5

\section{in acid drainage environment}

Pablo Cruz-Hernández ${ }^{\mathrm{a},}{ }^{*}$, Rafael Pérez-López ${ }^{\mathrm{a}}$, Annika Parviainen ${ }^{\mathrm{b}}$, Matthew B. J. Lindsay ${ }^{\mathrm{c}}$, José M. Nieto ${ }^{\text {a }}$

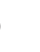
${ }^{\text {a }}$ Department of Geology, University of Huelva, Campus ‘El Carmen’, Huelva, E-21071, Spain ${ }^{\mathrm{b}}$ Instituto Andaluz de Ciencias de la Tierra, CSIC-UGR, Avda. de las Palmeras 4, Armilla, Granada, Spain ${ }^{\mathrm{c}}$ Department of Geological Sciences, University of Saskatchewan, Saskatoon, SK S7N 5E2, Canada

${ }^{*}$ Corresponding author. Tel.: +34-95-921-9826; fax: +34-95-921-9810

E-mail address: pablo.cruz@dgeo.uhu.es (P. Cruz-Hernández) 


\section{ABSTRACT}

15

Keywords: schwertmannite; goethite; hematite; acid drainage; trace elements behavior

Iron-rich sediments commonly cover riverbeds that have been affected by acid drainage associated with sulfide-mineral oxidation. Freshly-formed precipitates correspond to poorly-crystalline oxyhydroxysulfates that recrystallize over time. This study examined the distribution and mineral association of trace elements (e.g., $\mathrm{As}, \mathrm{Cu}, \mathrm{Zn})$ in modern and ancient ( $\sim 6 \mathrm{Ma}) \mathrm{Fe}$ terraces in the Tinto river basin, Spain. The mineral composition of the terraces was determined by Raman $\mu$-spectroscopy. Chemical digestions, electron probe microanalyses, and synchrotron-based $\mu$-X-ray fluorescence mapping were used to examine $\mathrm{As}, \mathrm{Cu}$, and $\mathrm{Zn}$ distribution and corresponding mineral associations. Fresh precipitates at modern terrace surfaces were dominated by schwertmannite, which contained high $\mathrm{As}, \mathrm{Cu}$, Mn, and Zn concentrations. However, schwertmannite transforms into goethite at short-time (weeks) in the deeper part of the current terraces and into hematite at century-time scale. Affinity for trace elements was generally highest in schwertmannite and lowest in hematite, which suggests that their retention by Fe terraces decreases during mineral transformation. Hence, schwertmannite acts as temporary sink for contaminants, which are again released at long-term during the maturation. These findings should be considered for management and treatment of possible water resources affected by acid mine drainage. 


\section{INTRODUCTION}

The natural weathering of outcropping sulfide ore bodies under meteoric conditions often produces acid rock drainage (ARD). Oxidative dissolution of sulfide minerals can lead to widespread acidification and contamination of water resources. Acid mine drainage (AMD) is generated where sulfide-mineral oxidation is accelerated, such as in mining operations that include excavations, earth works, and waste deposits. The consequences of AMD are generally more severe than ARD because mining activities increase exposed surface area of sulfide-bearing rocks (Amos et al., 2015; Lindsay et al., 2015; Olías et al., 2004; Webster et al., 1998). Dissolution of pyrite $\left[\mathrm{FeS}_{2}\right]$ and other sulfides in the presence of oxygen and water releases $\mathrm{Fe}(\mathrm{II})$ and $\mathrm{SO}_{4}$, and generates protons causing acidification of waters. Potentially hazardous trace elements (e.g., As, $\mathrm{Cu}, \mathrm{Zn}$ ) associated to sulfides are also liberated during oxidative dissolution. Subsequent oxidation of $\mathrm{Fe}(\mathrm{II})$ can promote spontaneous precipitation of $\mathrm{Fe}(\mathrm{III})$ oxyhydroxides and oxyhydroxysulfates from acid-sulfate waters. These waters host extremophile bacterial species such as Thiobacillus ferrooxidans and Leptospirillum ferrooxidans that catalyze Fe(II) oxidation and accelerate subsequent precipitation reactions (Boon and Heijnen, 1998; Leduc et al., 2002). Schwertmannite $\left[\mathrm{Fe}_{16} \mathrm{O}_{16}(\mathrm{OH})_{12}\left(\mathrm{SO}_{4}\right)_{2}\right]$ is thought to initially be the most thermodynamically stable phase in AMD impacted waters (Bigham et al., 1996). This poorly-crystalline oxyhydroxysulfate phase has a high capacity to sequester As and other potentially hazardous trace elements (FernandezMartinez et al., 2010; Fukushi et al., 2003, 2004). However, schwertmannite is metastable and transforms into more crystalline phases at $\mathrm{pH}$ 2-3 such as goethite $[\mathrm{FeO}(\mathrm{OH})]$ and jarosite $\left[\mathrm{KFe}_{3}\left(\mathrm{SO}_{4}\right)_{2}(\mathrm{OH})_{6}\right]$ within weeks (Bigham et al., 1996; Davidson et al., 2008). The pH regimes often favor goethite over jarosite precipitation because jarosite requires lower $\mathrm{pH}$ for its formation, in addition to considerably concentrations (Acero et al., 2006). Goethite can subsequently transform into hematite $\left[\mathrm{Fe}_{2} \mathrm{O}_{3}\right]$ over the long-term (centuries) through diagenetic processes (Davidson et al., 2008; Langmuir, 1971). Some studies have pointed out that transformation rates could be affected by high concentrations of trace elements. While the overall rate of schwertmannite transformation to more stable phases decreases with increasing arsenate (Fukushi et al., 2003) and, at a lesser extent, chromate (Regenspurg and Peiffer, 2005) solid loading, the apparent rate of hematite formation increases (Ford, 2002).

Formation of Fe terraces within AMD impacted rivers begins with accumulation and consolidation of schwertmannite on riverbeds (Cáceres et al., 2013). Transformation of schwertmannite into goethite, jarosite, and hematite has previously been observed in Fe terraces within AMD-impacted rivers (Asta et 
al., 2010; Parviainen et al., 2015; Pérez-López et al., 2011). Several laboratory studies have also examined the behavior of As and other trace elements during these transformations; however, the potential for trace element removal or release during these transformations remains unclear. Whereas some studies claim that As sorption capacity increases with crystallinity, particularly at low pH (Gimenez et al., 2007; Mamindy-Pajany et al., 2011), others indicate that As is preferentially retained in less crystalline phases (Bowell, 1994). In addition, relatively few studies have examined trace element behavior during mineral transformations in Fe terraces in field settings (Acero et al., 2006; Pérez-López et al., 2011). Moreover, the research reported shows new insights in different trace elements behavior and uses more precise techniques. Such conflicting results or simple lack of information is also the case for other trace elements. Thus, the main objective of this study was to examine the distribution of trace elements in Fe terraces to assess their potential long-term fate during schwertmannite transformation under natural conditions. Samples from two distinct terraces in the Tinto River basin in SW Spain were collected: one from a newly-formed modern terrace in an AMD-impacted river and one from an ancient Fe terrace away from the modern river channel. These ancient terraces were formed under similar conditions as the currently-formed terraces and were isolated due to the river migration over time (Amils et al., 2007; Fernández-Remolar, 2003).

\section{MATERIALS AND METHODS}

\subsection{Site description}

The Iberian Pyrite Belt (IPB) is one of the largest massive sulfide provinces in the world, with original massive sulfide reserves estimated at more than 1,700 Mt (Sáez et al., 1999). The IPB spans approximately $20,000 \mathrm{~km}^{2}$ and hosts more than 100 mines, the majority of which are currently inactive. Mining activity on the IPB began approximately 4,500 years ago (Nocete et al., 2014). Consequently, vast amounts of tailings and waste rock, and numerous open pits and underground workings, have exposed sulfide minerals to oxidative weathering and produced intense AMD. The legacy of the mining operations has severely degraded water quality in local catchments, which ultimately discharge from the Tinto and Odiel Rivers into the Atlantic Ocean. Consequently, these rivers account for a significant percentage of the total toxic element input to oceans worldwide (Nieto et al., 2013; Olías et al., 2016). Ore deposits are mainly comprised of Fe-rich sulfides such as pyrite $\left[\mathrm{FeS}_{2}\right]$, pyrrhotite $\left[\mathrm{Fe}_{(1-x)} \mathrm{S}\right]$, chalcopyrite $\left[\mathrm{CuFeS}_{2}\right]$, and arsenopyrite [FeAsS], plus other metalliferous minerals including sphalerite [ZnS] and galena [PbS]. 

del Hierro, and Corta Atalaya (Fig. 1a).

\subsection{Sample collection and preparation}

The river basins in the study area feature actively-forming modern terraces in AMD-affected rivers and ancient terraces that formed under similar conditions as the modern terraces but were isolated due to river migration over time (Amils et al., 2007; Fernández-Remolar, 2003). The age of the terraces denotes the maturation degree of the Fe phases. Thus, representative samples of the different stages of maturation were collected at El Alto de la Mesa (ancient terrace) and La Naya (modern terrace). The El Alto de la Mesa sample was collected from an ancient terrace consisting of an accumulation of Fe-oxides approximately $60 \mathrm{~m}$ above the modern riverbed (Fig. 1a,b). Stratigraphically, this terrace is defined as a fluvial point-bar sequence that was formed around $6 \mathrm{Ma}$ ago (Messinian age) according to paleomagnetic dating (Essalhi et al., 2011). The modern terrace sample was collected from a freshly-formed terrace in a tributary of the Tinto River in the inactive Zarandas-La Naya mining area (Fig. 1a,c). Physicochemical parameters of the AMD-affected stream were measured in situ in the moment of the sample collection using a portable Multiparametric Crison $\mathrm{MM} 40+$ equipment $(\mathrm{pH}=2.53$, redox potential $=423 \mathrm{mV}$, electrical conductivity $=10.9 \mathrm{mS} / \mathrm{cm}$ ). The sample thickness was approximately $10 \mathrm{~cm}$, which represented the most recent sedimentation sequence. desiccant to minimize any mineralogical transformations. Subsamples of interest from both terraces were selected, ground using an agate mortar and pestle, and subjected to conventional geochemical and mineralogical analysis. In addition, undisturbed samples from both terraces were prepared as polished thin sections; these were embedded in polyester epoxy, mounted on quartz glass slides using polyester resin, and polished to a final thickness of approximately $50 \mu \mathrm{m}$. All polishing was performed without water to avoid dissolution of water-soluble phases.

\subsection{Geochemical and mineralogical analyses}

The modern terraces are earthy and porous in nature, which limits the use of point techniques for quantitative chemical microanalysis (Cáceres et al., 2013). Thus, subsamples for detailed geochemical analyses were taken corresponding to color changes with depth. In contrast, bulk chemical analyses of the 
ancient terrace were conducted because separation was not possible. Subsamples of the modern terrace along with bulk ancient terrace samples ( 2 replicates per sample) were digested in aqua regia prepared using a 1:3 molar ratio of $\mathrm{HNO}_{3}$ to $\mathrm{HCl}$ and heated at $90{ }^{\circ} \mathrm{C}$ to pseudo-dry the solution. These samples were then re-dissolved in $50 \mathrm{~mL}$ of a $10 \% \mathrm{HNO}_{3}$ solution and analyzed for major and trace elements by inductively coupled plasma-optical emission spectrometry (ICP-OES, Thermo Jarrel-Ash) and inductively coupled plasma-mass spectrometry (ICP-MS, X-series II Thermo), respectively.

An optical microscope (Nikon Eclipse LV100POL) operating in reflected light mode was used to examine mineralogical and textural characteristics of the samples in thin sections. Raman $\mu$-spectroscopy can be used to identify Fe phases of varied crystallinity (e.g. Das and Hendry, 2011). Thus, Raman spectra were collected at the Instituto Andaluz de Ciencias de la Tierra (Granada, Spain) according to methods described in detail by (Parviainen et al., 2015). Briefly, the Raman microscope (LabRAM HR, Jobin-Yvon Horiba, Japan) was operated in backscattering geometry with a $784 \mathrm{~nm}$ excitation beam focused using a confocal microscope (Olympus). Two to four replicate Raman spectra were collected using a Peltier-cooled charge coupled device (CCD) detector and $300 \mathrm{~s}$ acquisition time. Mineral transformations and sample degradation were minimized by using D0.3 and D0.6 filters, which were checked with synthetic and natural standards of known composition. A resolution of $3 \mathrm{~cm}^{-1}$ and spectral range of 150 to $1,350 \mathrm{~cm}^{-1}$ were used. Furthermore, bulk powder X-ray diffraction (XRD) was performed by using PANanalytical X'Pert PRO with $\mathrm{Cu} \mathrm{K \alpha}$ radiation at the Instituto Andaluz de Ciencias de la Tierra. Diffractometer settings were: $45 \mathrm{kV}, 40 \mathrm{~mA}$, and a scan range of $4-60^{\circ} 2 \theta$ and $4-70^{\circ} 2 \theta$ for newlyformed and ancient samples, respectively, with $0.0084^{\circ} 2 \theta$ step size and 100 -s counting time per step. The results of XRD were consistent with the Raman spectroscopy observations and, for this reason, they are provided as supplementary data (Fig. S1).

Thin sections were also graphite coated and examined using an electron probe microanalyzer 153 (EPMA) at the University of Huelva (Huelva, Spain). Unlike the modern terrace, the ancient sample is a 154 hard mass of consolidated Fe phases that permits the use of point techniques for quantitative chemical microanalysis. Thus, imaging of both terraces and quantitative geochemical analysis of the ancient terrace sample were carried out with a four-spectrometer EPMA (JXA-8200 Superprobe, JEOL Ltd., Japan) using a $5 \mu \mathrm{m}$ beam and $15 \mathrm{KeV}$ acceleration voltage. Metallic oxides, sulfides, and silicates were used as standards. Numerous analyses $(n=100)$ were performed on areas identified by optical microscopy and Raman $\mu$-spectroscopy. 


\subsection{Micro-X-ray fluorescence mapping}

Synchrotron-based $\mu$-X-ray fluorescence ( $\mu$-XRF) mapping of sample thin sections was performed

163

164

165

166

167

168

169

170

171

172

173

174

175

176

177

178

179

180

\section{1}

182

183

184

185

186

187

188

189

to examine the distribution of the main AMD-related elements (e.g., $\mathrm{As}, \mathrm{Cu}, \mathrm{Zn}$ ) and to identify the association of these elements with the Fe mineral phases. Target areas were selected based on the mineralogical examination, and graphite coatings were removed prior to analysis by polishing again the samples. The $\mu$-XRF maps were obtained on the GeoSoilEnviroCARS beamline 13-ID-E at the Advanced Photon Source (Chicago, USA). The storage ring was operated in continuous top-up mode at a current of approximately $102 \mathrm{~mA}$ during mapping. The cryo-cooled monochrometer setup used two Si(111) crystals to select an incident X-ray energy of $30 \mathrm{keV}$. The micro-focused X-ray beam had a spot size of $2 \times 2 \mu \mathrm{m}$ and the samples were rastered using a $2-\mu \mathrm{m}$ step size and a 50-ms dwell time. A four-element silicon drift detector (Vortex ${ }^{\circledR}-M E 4$, Hitatchi High Technologies America, Inc.) was used to obtain fluorescence spectra; three layers of $\mathrm{Al}$ foil were placed over the detector to filter a portion of the Fe signal and avoid detector saturation. Processing and analysis of $\mu$-XRF data were done using Larch (Newville, 2001) and PyMCA (Solé et al., 2007) software packages. Moreover, principal component analysis (PCA) was performed with XLSTAT-Pro v7.5.2 to reduce the $\mu$-XRF data in the different mineralogical zones of each terrace. Pearson correlation was used as an index of similarity and $p$-values were fixed at 0.05 . The two first principal components (PC1 and PC2) were considered the most informative and simplest way to display the PCA results.

\section{RESULTS}

\subsection{Modern terraces}

The upper part of the newly-formed modern terrace was exclusively dominated by schwertmannite from surface to a depth of 0.5 to $1 \mathrm{~cm}$. The relative proportion of goethite then progressively increased with depth. Raman spectra obtained from the upper part of this sample exhibit characteristic schwertmannite bands at 298, 320, 350, 418, 544, 580, 713, and $980 \mathrm{~cm}^{-1}$ (Fig. 2a; Burton et al., 2009; Mazzetti and Thistlethwaite, 2002; Parviainen et al., 2015). Characteristic bands for goethite at 247, 378, and $470 \mathrm{~cm}^{-1}$ appear with increasing depth, while other bands at 298 and $544 \mathrm{~cm}^{-1}$ overlap with those of schwertmannite (Fig. 2b; Müller et al., 2010; Parviainen et al., 2015). A typical X-ray fluorescence spectrum is also shown in Figure S2 (see supplementary materials). Although schwertmannite and 
goethite cannot be clearly and individually recognized in the EPMA images, some textural differences along the samples are evident. Schwertmannite in the surface part occurs as porous spherical microaggregates (Fig. S2b), whereas the schwertmannite and goethite mixture observed in deeper layers appear less porous and exhibit a botryoidal texture typical of goethite (Fig. S2c). Jarosite is present as a minor phase in deeper layers of the newly-formed terrace, as shown by some Raman spectra with characteristic jarosite bands at 225, 301, 353, 436, 455, 570, 630, and $1000 \mathrm{~cm}^{-1}$ (Fig. 2c; CourtinNomade et al., 2003; Filippi et al., 2007; Frost et al., 2005).

Mineralogical observations appear congruent with the chemical composition changes with depth based on the pseudo-total digestion results (Table 1). The progressive transformation of schwertmannite into goethite is reflected by a decrease in $\mathrm{S}$ (from 13 to $10 \mathrm{wt} \%$ as $\mathrm{SO}_{3}$ ) and an increase in $\mathrm{Fe}$ (from 44 to 57 wt. $\%$ as $\mathrm{Fe}_{2} \mathrm{O}_{3}$ ) concentrations in the solid. An increase in the $\mathrm{K}$ content with depth (from 0.3 to 2 wt. $\%$ as $\mathrm{K}_{2} \mathrm{O}$ ) can be attributed to the minor occurrence of jarosite. Concentrations of metals typical of $\mathrm{AMD}$ (e.g., $\mathrm{As}, \mathrm{Cu}, \mathrm{Zn}$ ) are slightly elevated in the uppermost layers but do not show a specific trend with depth (Table 1). These findings are also in agreement with two $\mu$-XRF maps performed on the newly-formed modern terrace, one for the upper schwertmannite section (Fig. 3b) and the other for the deeper schwertmannite and goethite section (Fig. 3c). The maps confirm that fluorescence intensities for $\mathrm{As}, \mathrm{Cu}$, and $\mathrm{Zn}$ are slightly higher in the first few micrometers of the uppermost micro-section that features fresher schwertmannite. However, spatial distribution of these elements in the remainder of the terrace sample is generally homogeneous across the micro-sections analyzed. Therefore, chemical composition does not appear to be substantially controlled by the mineralogical variation in these samples, most likely due to the low crystallinity of the newly-formed goethite, as discussed below.

\subsection{Ancient terraces}

The ancient terrace sample exhibits well-defined bands of individual hematite and goethite, but

214 hematite is the main phase comprising the sample matrix. Raman micro-spectra of the goethite bands exhibit peaks at $159,204,245,300,390,470,550$, and $690 \mathrm{~cm}^{-1}$ (Fig. 2d). The width of the goethite bands in the Raman spectra decreases from modern terrace to older terrace, which indicates higher crystallinity of the goethite in the older terrace. Hematite peaks appear at 230, 250 (minor), 297, 401, 489, and $610 \mathrm{~cm}^{-1}$ (Fig. 2e Das and Hendry, 2011; Müller et al., 2010; Parviainen et al., 2015). An X-ray fluorescence spectrum of a modern terrace sample is provided in Figure S3. EPMA images reveal the 
presence of botryoidal and colloform textures where hematite appears to have largely replaced goethite as the dominant phase (Fig. 4a). Some detrital quartz grains are also evident. $\mathrm{Fe}_{2} \mathrm{O}_{3}$ ), as expected; $\mathrm{S}$ is a minor component $\left(0.6 \mathrm{wt} . \%\right.$ as $\mathrm{SO}_{3}$; Table 1$)$. The remainder is composed of $\mathrm{Al}, \mathrm{Na}, \mathrm{As}, \mathrm{Pb}$, and $\mathrm{Cu}$, while $\mathrm{Zn}$ is almost undetectable (Table 1). Unlike the modern terrace, $\mu-\mathrm{XRF}$ mapping reveals that elemental distribution within the ancient terrace sample is strongly linked to mineralogy. $\mathrm{As}, \mathrm{Cu}$, and $\mathrm{Zn}$ generally exhibit higher fluorescence intensities in areas featuring goethite bands than in those featuring hematite bands (Fig. $4 \mathrm{~b}$ ). Fluorescence intensity profiles for $\mathrm{As}, \mathrm{Cu}$, and $\mathrm{Zn}$ across the ancient terrace sample further illustrate the greater affinity of these elements for goethite vs. hematite (Fig. 5). In addition, EPMA analysis results throughout this micro-section are generally consistent with the trace element information from the $\mu$-XRF map. Iron concentrations are slightly higher in areas featuring hematite ( $83 \pm 0.75 \mathrm{wt} . \%$; mean \pm standard deviation) than those featuring goethite $(73 \pm 0.84$ wt.\%). However, $\mathrm{S}$ and trace elements concentrations are higher in the goethite bands (e.g., $1.2 \pm 0.11$ wt.\% for $\mathrm{S}$ as $\mathrm{SO}_{3} ; 3394 \pm 1006 \mathrm{mg} / \mathrm{kg}$ for As; $1305 \pm 414 \mathrm{mg} / \mathrm{kg}$ for $\mathrm{Cu} ; 746 \pm$ $237 \mathrm{mg} / \mathrm{kg}$ for $\mathrm{Zn}$ on average) than in the hematite bands (e.g., $0.58 \pm 0.08$ wt.\% for $\mathrm{S}^{2} \mathrm{SO}_{3} ; 2084 \pm 393$ $\mathrm{mg} / \mathrm{kg}$ for As; values below or close to the detection limit for $\mathrm{Cu}$ and $\mathrm{Zn}$ ) (Table 2). Although no fluorescence data for $\mathrm{Pb}$ are available, EPMA analyses show that $\mathrm{Pb}$ is the only trace element with consistently higher concentrations in hematite $(2254 \pm 315 \mathrm{mg} / \mathrm{kg})$ than in goethite $(1704 \pm 569 \mathrm{mg} / \mathrm{kg}$; Table 2). Notably, the As distribution is discordant with that of $\mathrm{Cu}$ and $\mathrm{Zn}$ within the goethite bands, i.e., higher $\mathrm{As}$ and lower $\mathrm{Cu}$ and $\mathrm{Zn}$ intensities, or vice versa (Fig. 5). The distribution of these heterogeneities, parallel to the formation of the different bands in the ancient sample, can be attributed to temporal changes in the initial composition.

\section{DISCUSSION}

The geochemical and mineralogical composition of the terrace samples reflects the gradual maturation of poorly-crystalline early precipitates into more crystalline and stable phases, which aligns with previous studies (e.g., Acero et al., 2006; Pérez-López et al., 2011). The fresh AMD-precipitates are comprised of schwertmannite; however, analysis of still-unconsolidated sediments reveals that this poorly-crystalline Fe phase is transformed over the short term into goethite and occasionally jarosite. Over the long term, goethite recrystallizes and is replaced by hematite following textural evidences of 
replacement in the bands (Fig. 5). In Raman spectra, fresher goethite associated with modern terraces has less well-defined bands than the more crystalline goethite present in ancient terraces. Consistent with the mineralogical transformation, the bulk concentrations of Fe and S increase and decrease, respectively, with increasing crystallinity, i.e., from the schwertmannite-dominated newly-formed terrace to the hematite-dominated ancient terrace. Obviously, sulfate release occurs during the transformation from iron oxyhydroxysulfates to oxyhydroxides and oxides (Bigham et al., 1996).

Comparing absolute concentrations of trace elements in the ancient and modern terraces is meaningless because the chemistry of these elements in the AMD and, hence, in the precipitates varies strongly depending on the type of ore deposit, degree of exposure, distance to the source, etc. (Sarmiento et al., 2009). The microenvironments in which ancient terraces formed $6 \mathrm{Ma}$ ago are completely unknown. Nevertheless, it is possible to compare the behavior of the trace elements during transformation from schwertmannite to fresh goethite over the short term in the modern terrace and from more crystalline goethite to hematite over the long term in the ancient terrace. Conventional geochemical characterization (i.e., pseudo-total digestion and EPMA) provides results consistent with synchrotron radiation $\mu$-XRF; however, the large database of intensities obtained in each $\mu$-XRF map $(\sim 500,000$ point spectra) allows PCA to be performed to statistically compare the affinity of contaminants for each phase (i.e., between mineralogical layers) and to determine element behavior during the aging process.

In the newly-formed terrace, trace element concentrations exhibit little spatial variation during the aging of schwertmannite to goethite. In the upper part of the sample (first $1 \mathrm{~mm}$ ) where schwertmannite is the only phase detected, the two first principal components account for $84 \%$ of the total variance in the data. Iron is the predominant element and its spatial distribution in the $\mu$-XRF is highly correlated with $\mathrm{S}$ $\left(R^{2}=0.81\right)$, in agreement with the occurrence of schwertmannite, and with metals, mainly As $\left(R^{2}=0.92\right)$ along with $\mathrm{Cu}\left(R^{2}=0.78\right), \mathrm{Mn}\left(R^{2}=0.74\right)$, and $\mathrm{Zn}\left(R^{2}=0.65\right)$. These elements are strongly grouped with positive loading on the first principal component axis (Fig. 6a). Hence, schwertmannite exhibits a high affinity for most of the contaminants in solution. goethite is detected, revealed that the two first principal components account for $88 \%$ of the total variance in the data. In this zone, $\mathrm{Fe}$ is still positively correlated with $\mathrm{As}\left(R^{2}=0.88\right), \mathrm{Cu}\left(R^{2}=0.76\right), \mathrm{Mn}\left(R^{2}=\right.$ $0.70), \mathrm{S}\left(R^{2}=0.71\right)$, and, to a lesser extent, $\mathrm{Zn}\left(R^{2}=0.60\right)$ along the first component axis (Fig. 6b).

279 However, comparison of both areas demonstrates that the aging from schwertmannite to goethite with 
depth in the newly-formed terraces seems to be accompanied by a slight decrease in affinity for contaminants, which could be related to a possible partial release to the environment. Nevertheless, the loss of correlation is not substantial and the elevated affinity of the solid phase by trace elements remains throughout the transformation during the early maturation stages of schwertmannite to goethite. These findings are in agreement with previous observations reported for As by Acero et al. (2006) in laboratory experiments, which show that, although slight release into solution occurs, more than $99 \%$ remains in the solid phase during the aging of schwertmannite to goethite over short timescales (nearly one year). In contrast, trace element content within the ancient terrace is highly dependent on the mineralogy. Plots of the two first principal components for the goethite and hematite mineralogical zones show they account for 62 and $69 \%$ of the total variance in the data, respectively. Analysis of the goethite layers confirms that complete transformation of schwertmannite to goethite is accompanied by a loss of affinity for contaminants. The spatial distribution of $\mathrm{Fe}$ is more weakly correlated to As $\left(R^{2}=0.21\right)$ and negatively correlated to $\mathrm{Cu}\left(R^{2}=-0.62\right), \mathrm{Mn}\left(R^{2}=-0.51\right), \mathrm{S}\left(R^{2}=-0.46\right)$, and $\mathrm{Zn}\left(R^{2}=-0.21\right)$ (Fig. 6c). This dispersion of elements in the plot is more significant in the hematite layers, where Fe distribution shows a strong negative correlation with all elements of the system: As $\left(R^{2}=-0.51\right), \mathrm{Cu}\left(R^{2}=-0.69\right), \mathrm{Mn}$ $\left(R^{2}=-0.70\right), \mathrm{S}\left(R^{2}=-0.82\right)$, and $\mathrm{Zn}\left(R^{2}=-0.12\right)$ (Fig. 6d). Therefore, the aging of schwertmannite to goethite and goethite to hematite over time could be accompanied by the potential release of trace elements previously retained by the freshly-formed phases. Obviously one can not attribute the increase in mobility of trace elements exclusively to the long-term aging of Fe phases; e.g. weathering with meteoric water could also contribute to the desorption processes. Although no fluorescence data are available for $\mathrm{Pb}, \mathrm{EMPA}$ analyses indicate this metal is particularly concentrated in more crystalline phases with aging, a tendency contrary to the other trace elements studied. In fact, some studies reported that the sorption strength on iron oxyhydroxides is relatively higher for $\mathrm{Pb}$ than for other metals (Liu et al., 2014). These results provide clarity with respect to questions raised in the introduction about As behavior and are consistent with previous studies (Bowell, 1994; Pérez-López et al., 2011); they also provide new information with respect to other potentially hazardous trace elements. water quality in AMD-affected river basins under different scenarios. Models must carefully integrate processes of AMD generation, contaminant transport, and natural attenuation by precipitation of schwertmannite. According to our results, the metastability of these precipitates may determine pollutant 
fluxes over time in these environmental systems: Fe precipitates could initially act as a sink for trace elements, but later become a long-term source of pollution. This increase in contaminant mobility with aging should be considered in the development of conceptual models. Moreover, these models must serve to optimize the design and location of treatment systems that decrease pollution in the fluvial environment. Dispered Alkaline Substrate-type treatment systems for highly-polluted AMD use a reactive mixture of wood chips and an alkaline additive to neutralize acidity and remove contaminants by induced precipitation of schwertmannite (Macías et al., 2012). Due to the large amount of wood, calcination is one option being considered to decrease the volume and ease the handling of wastes from AMD treatment. Based on the current study, waste burning would cause a forced aging of schwertmannite and, hence, an increase in the potential release of contaminants by leaching that must be taken into account for proper management of these wastes.

\section{CONCLUSIONS}

This study was performed to fill a gap in our knowledge about the long-term fate of some of the main pollutants retained in Fe terraces formed along riverbeds impacted by acid mine drainage (AMD). Comprehensive analyses including chemical digestion, Raman $\mu$-spectroscopy, electron probe microanalysis, and synchrotron-based $\mu$-X-ray fluorescence were performed on iron terrace samples taken in fluvial courses of the Iberian Pyrite Belt (SW Iberian Peninsula). Samples were taken from activelyforming modern terraces as well as ancient terraces isolated due to river migration over time. Schwertmannite was the main newly-formed phase precipitated from the polluted water and comprised the upper part of modern terraces. This schwertmannite was highly positively correlated to As as well as $\mathrm{Cu}, \mathrm{Mn}, \mathrm{S}$, and $\mathrm{Zn}$, indicating that this phase may have controlled the uptake of these elements. However, progressive maturation of schwertmannite to goethite in the deeper part of modern terraces and especially in ancient terraces appears responsible for a decrease in this correlation and hence an increase in element mobility. This loss of affinity for contaminants is particularly evident in the hematite resulting from the transformation of goethite in the ancient terraces. The spatial distribution of hematite is negatively correlated with the concentration of most trace elements; $\mathrm{Pb}$ was the only trace element to show a higher affinity for this most crystalline phase after aging. Therefore, schwertmannite that retains contaminants in the newly-formed sediments may serve as a long-term source of these contaminants to the environment due to mineralogical transformations. 


\section{ACKNOWLEDGMENTS}

342 This research was financed by the Spanish Ministry of Economy and Competitiveness through the 343 EMPATIA project (Ref. CGL2013-48460-C2-1-R). The work of Dr. A. Parviainen was funded by the 344 KAUTE Foundation, Finland. Dr. R. Pérez-López acknowledges the Spanish Ministry of Science and 345 Innovation and the 'Ramón y Cajal Subprogramme' (MICINN-RYC 2011). P. Cruz-Hernández was 346 supported by a graduate scholarship from the Spanish Ministry of Economy and Competitiveness 347 (METODICA, CGL2010-21956-C02-02). Dr. Lindsay acknowledges support from the NSERC 348 Discovery Grants Program (Grant No. RGPIN-2014-06589). Portions of this research were performed at 349 GeoSoilEnviroCARS (Sector 13), Advanced Photon Source (APS), Argonne National Laboratory. 350 GeoSoilEnviroCARS is supported by the National Science Foundation - Earth Sciences (EAR-1128799) 351 and Department of Energy - GeoSciences (DE-FG02-94ER14466). This research used resources of the 352 Advanced Photon Source, a U.S. Department of Energy (DOE) Office of Science User Facility operated 353 for the DOE Office of Science by Argonne National Laboratory under Contract No. DE-AC02354 06CH11357. We would also like to thank Dr. Markus Egli (Editor) and two anonymous reviewers for the 355 support and comments that significantly improved the quality of the original paper. 


\section{REFERENCES}

Acero, P., Ayora, C., Torrentó, C., Nieto, J.M., 2006. The behavior of trace elements during schwertmannite precipitation and subsequent transformation into goethite and jarosite. Geochim. Cosmochim. Acta 70, 4130-4139. doi:10.1016/j.gca.2006.06.1367

Amils, R., González-Toril, E., Fernández-Remolar, D., Gómez, F., Aguilera, Á., Rodríguez, N., Malki, M., García-Moyano, A., Fairén, A.G., de la Fuente, V., Luis Sanz, J., 2007. Extreme environments as Mars terrestrial analogs: The Rio Tinto case. Planet. Space Sci. 55, 370-381. doi:10.1016/j.pss.2006.02.006

Amos, R.T., Blowes, D.W., Bailey, B.L., Sego, D.C., Smith, L., Ritchie, I.M., 2015. Waste-rock hydrogeology and geochemistry. Appl. Geochemistry 57, 140-156. doi:10.1016/j.apgeochem.2014.06.020

Asta, M.P., Ayora, C., Román-Ross, G., Cama, J., Acero, P., Gault, A.G., Charnock, J.M., Bardelli, F., 2010. Natural attenuation of arsenic in the Tinto Santa Rosa acid stream (Iberian Pyritic Belt, SW Spain): The role of iron precipitates. Chem. Geol. 271, 1-12. doi:10.1016/j.chemgeo.2009.12.005

Bigham, J.M., Schwertmann, U., Traina, S.J., Winland, R.L., Wolf, M., 1996. Schwertmannite and the chemical modeling of iron in acid sulfate waters. Geochim. Cosmochim. Acta 60, 2111-2121. doi:10.1016/0016-7037(96)00091-9

Boon, M., Heijnen, J.., 1998. Chemical oxidation kinetics of pyrite in bioleaching processes. Hydrometallurgy 48, 27-41. doi:10.1016/S0304-386X(97)00072-8

Bowell, R.J., 1994. Sorption of arsenic by iron-oxides and oxyhydroxides in soils. Appl. Geochemistry 9, $279-286$.

Burton, E.D., Bush, R.T., Johnston, S.G., Watling, K.M., Hocking, R.K., Sullivan, L. a., Parker, G.K., 2009. Sorption of Arsenic(V) and Arsenic(III) to schwertmannite. Environ. Sci. Technol. 43, 92029207. doi:10.1021/es902461x

Cáceres, L.M., Olías, M., De Andrés, J.R., Rodríguez-Vidal, J., Clemente, L., Galván, L., Medina, B., 2013. Geochemistry of Quaternary sediments in terraces of the Tinto River (SW Spain): Paleoenvironmental implications. Catena 101, 1-10. doi:10.1016/j.catena.2012.09.011

Courtin-Nomade, A., Bril, H., Neel, C., Lenain, J.-F., 2003. Arsenic in iron cements developed within tailings of a former metalliferous mine-Enguialès, Aveyron, France. Appl. Geochemistry 18, 395408. doi:10.1016/S0883-2927(02)00098-7 
387

388

389

390

391

392

393

394

395

396

397

398

399

400

401

402

403

404

405

406

407

408

409

410

411

412

413

414

415

416

Das, S., Hendry, M.J., 2011. Application of Raman spectroscopy to identify iron minerals commonly found in mine wastes. Chem. Geol. 290, 101-108. doi:10.1016/j.chemgeo.2011.09.001

Davidson, L.E., Shaw, S., Benning, L.G., 2008. The kinetics and mechanisms of schwertmannite transformation to goethite and hematite under alkaline conditions. Am. Mineral. 93, 1326-1337. doi:10.2138/am.2008.2761

Essalhi, M., Sizaret, S., Barbanson, L., Chen, Y., Lagroix, F., Demory, F., Nieto, J.M., Sáez, R., Capitán, M.Á., 2011. A case study of the internal structures of gossans and weathering processes in the Iberian Pyrite Belt using magnetic fabrics and paleomagnetic dating. Miner. Depos. 46, 981-999. doi:10.1007/s00126-011-0361-8

Fernandez-Martinez, A., Timon, V., Romaman-Ross, G., Cuello, G.J., Daniels, J.E., Ayora, C., 2010. The structure of schwertmannite, a nanocrystalline iron oxyhydroxysulfate. Am. Mineral. 95, 13121322. doi:10.2138/am.2010.3446

Fernández-Remolar, D.C., 2003. Geological record of an acidic environment driven by iron hydrochemistry: The Tinto River system. J. Geophys. Res. 108, 1-15. doi:10.1029/2002JE001918

Filippi, M., Doušová, B., Machovič, V., 2007. Mineralogical speciation of arsenic in soils above the Mokrsko-west gold deposit, Czech Republic. Geoderma 139, 154-170. doi:10.1016/j.geoderma.2007.01.015

Ford, R.G., 2002. Rates of hydrous ferric oxide crystallization and the influence on coprecipitated arsenate. Environ. Sci. Technol. 36, 2459-2463. doi:10.1021/es015768d

Frost, R.L., Wills, R.A., Weier, M.L., Martens, W., 2005. Comparison of the Raman spectra of natural and synthetic K- and Na-jarosites at 298 and 77 K. J. Raman Spectrosc. 36, 435-444. doi:10.1002/jrs.1317

Fukushi, K., Sato, T., Yanase, N., 2003. Solid-solution reactions in As(V) sorption by schwertmannite. Environ. Sci. Technol. 37, 3581-3586. doi:10.1021/es026427i

Fukushi, K., Sato, T., Yanase, N., Minato, J., Yamada, H., 2004. Arsenate sorption on schwertmannite. Am. Mineral. 89, 1728-1734.

Gimenez, J., Martinez, M., de Pablo, J., Rovira, M., Duro, L., 2007. Arsenic sorption onto natural hematite, magnetite, and goethite. J. Hazard. Mater. 141, 575-580. doi:10.1016/j.jhazmat.2006.07.020

Langmuir, D., 1971. Particle size effect on the reaction goethite $=$ hematite + water.pdf. Am. J. Sci. 
Leduc, D., Leduc, L.G., Ferroni, G.D., 2002. Quantification of bacterial populations indigenous to acidic drainage streams. Water. Air. Soil Pollut. 135, 1-21. doi:10.1023/A:1014778301817

Lindsay, M.B.J., Moncur, M.C., Bain, J.G., Jambor, J.L., Ptacek, C.J., Blowes, D.W., 2015. Geochemical and mineralogical aspects of sulfide mine tailings. Appl. Geochemistry 57, 157-177. doi:10.1016/j.apgeochem.2015.01.009

Liu, H., Chen, T., Frost, R.L., 2014. An overview of the role of goethite surfaces in the environment. Chemosphere 103, 1-11. doi:10.1016/j.chemosphere.2013.11.065

Macías, F., Caraballo, M.A., Rotting, T.S., Perez-Lopez, R., Nieto, J.M., Ayora, C., 2012. From highly polluted Zn-rich acid mine drainage to non-metallic waters: Implementation of a multi-step alkaline passive treatment system to remediate metal pollution. Sci. Total Environ. 433, 323-330. doi:10.1016/j.scitotenv.2012.06.084

Mamindy-Pajany, Y., Hurel, C., Marmier, N., Roméo, M., 2011. Arsenic (V) adsorption from aqueous solution onto goethite, hematite, magnetite and zero-valent iron: Effects of $\mathrm{pH}$, concentration and reversibility. Desalination 281, 93-99. doi:10.1016/j.desal.2011.07.046

Mazzetti, L., Thistlethwaite, P.J., 2002. Raman spectra and thermal transformations of ferrihydrite and schwertmannite. J. Raman Spectrosc. 33, 104-111. doi:10.1002/jrs.830

Müller, K., Ciminelli, V.S.T., Dantas, M.S.S., Willscher, S., 2010. A comparative study of As(III) and $\mathrm{As}(\mathrm{V})$ in aqueous solutions and adsorbed on iron oxy-hydroxides by Raman spectroscopy. Water Res. 44, 5660-5672. doi:10.1016/j.watres.2010.05.053

Newville, M.G., 2001. IFEFFIT: Interactive XAFS analysis and FEFF fitting. J. Synchrotron Radiat. 8, 322-324. doi:10.4135/9781412983846

Nieto, J.-M., Sarmiento, A.M., Cánovas, C.R., Olías, M., Ayora, C., 2013. Acid mine drainage in the Iberian Pyrite Belt: 1. Hydrochemical characteristics and pollutant load of the Tinto and Odiel Rivers. Environ. Sci. Pollut. Res. Int. 20, 7509-7519. doi:10.1007/s11356-013-1634-9

Nocete, F., Sáez, R., Bayona, M.R., Nieto, J.M., Peramo, A., López, P., Gil-Ibarguchi, J.I., Inácio, N., García, S., Rodríguez, J., 2014. Gold in the Southwest of the Iberian Peninsula during the 3rd Millennium BC. J. Archaeol. Sci. 41, 691-704. doi:10.1016/j.jas.2013.10.006

Olías, M., Nieto, J.M., Pérez-Lépez, R., Cánovas, C.R., Macías, F., Sarmiento, A.M., Galván, L., 2016. Controls on acid mine water composition from the Iberian Pyrite Belt (SW Spain). Catena 137, 12 23. doi:10.1016/j.catena.2015.08.018 
Olías, M., Nieto, J.M., Sarmiento, a. M., Cerón, J.C., Cánovas, C.R., 2004. Seasonal water quality variations in a river affected by acid mine drainage: The Odiel River (South West Spain). Sci. Total Environ. 333, 267-281. doi:10.1016/j.scitotenv.2004.05.012

Parviainen, A., Cruz-Hernández, P., Pérez-López, R., Nieto, J.M., Delgado-López, J.M., 2015. Raman

451

452 identification of Fe precipitates and evaluation of As fate during phase transformation in Tinto and Odiel River Basins. Chem. Geol. 398, 22-31. doi:10.1016/j.chemgeo.2015.01.022

454

Pérez-López, R., Asta, M.P., Román-Ross, G., Nieto, J.M., Ayora, C., Tucoulou, R., 2011. Synchrotronbased X-ray study of iron oxide transformations in terraces from the Tinto-Odiel river system: Influence on arsenic mobility. Chem. Geol. 280, 336-343. doi:10.1016/j.chemgeo.2010.11.021

Regenspurg, S., Peiffer, S., 2005. Arsenate and chromate incorporation in schwertmannite. Appl.

Sáez, R., Pascual, E., Toscano, M., Almodóvar, G.R., 1999. The Iberian type of volcano-sedimentary massive sulphide deposits. Miner. Depos. 34, 549-570. doi:10.1007/s001260050220

Sarmiento, A.M., Olías, M., Nieto, J.M., Cánovas, C.R., Delgado, J., 2009. Natural attenuation processes in two water reservoirs receiving acid mine drainage. Sci. Total Environ. 407, 2051-2062.

463 doi:10.1016/j.scitotenv.2008.11.011

Solé, V. a., Papillon, E., Cotte, M., Walter, P., Susini, J., 2007. A multiplatform code for the analysis of energy-dispersive X-ray fluorescence spectra. Spectrochim. Acta - Part B At. Spectrosc. 62, 63-68. doi:10.1016/j.sab.2006.12.002

Webster, J.G., Swedlund, P.J., Webster, K.S., 1998. Trace Metal Adsorption onto an Acid Mine Drainage Iron ( III ) Oxy Hydroxy Sulfate. Environ. Sci ence Technol. 32, 1361-1368. doi:DOI: 
FIGURE 1. Detailed map of the study area showing: (a) sampling locations, (b) an image of the Alto de la Mesa ancient terrace outcrop, and (c) images of the newly-formed La Naya terrace.

FIGURE 2. Representative micro-Raman spectra of (a) schwertmannite, (b) a mixture of schwertmannite and goethite and (c) jarosite in the newly-formed terrace sample, and (d) goethite and (e) hematite in the ancient terrace sample.

FIGURE 3. (a) EPMA image of the newly-formed terrace sample with the micro cross-sections analyzed by synchrotron- $\mu$-XRF: (b) and (c) elemental distribution maps for the upper part and the deeper part, respectively. For interpretation of colors, the reader is referred to the web version of this paper.

FIGURE 4. (a) EPMA image of the micro cross-section analyzed in the ancient terrace sample by synchrotron- $\mu$-XRF: (b) elemental distribution maps. For interpretation of colors, the reader is referred to the web version of this paper.

FIGURE 5. Variation of the relative fluorescence intensity of $\mathrm{As}, \mathrm{Cu}$, and $\mathrm{Zn}$ along the ancient terrace. Hematite and goethite levels are differentiated (light grey $=$ hematite; dark grey $=$ goethite)

FIGURE 6. Projections of the element intensities obtained by $\mu$-XRF mapping on a plot of the two first principal components from the PCA results for the: (a) upper part of the newly-formed terrace with schwertmannite (sch), (b) deeper part of the newly-formed terrace with a mixture of schwertmannite

TABLE CAPTIONS and goethite (gt), (c) goethite levels of the ancient terrace, and (d) hematite (hem) levels of the ancient terrace. Principal component loadings of elemtns in each analysis are shown in Table S1 (see supplementary materials). terrace. Depth intervals match those shown in Figure 5. 


\section{Table 1}

\begin{tabular}{|c|c|c|c|c|c|c|}
\hline \multirow[b]{2}{*}{ Sample } & \multicolumn{5}{|c|}{ LN depth (cm) } & \multirow[b]{2}{*}{ AM } \\
\hline & $0-1$ & $1-2$ & $2-4$ & $4-7$ & $7-11$ & \\
\hline & \multicolumn{5}{|c|}{ Majorelements (\%) } & \\
\hline $\mathrm{Al}_{2} \mathrm{O}_{3}$ & 0.30 & 0.28 & 0.17 & 0.15 & 0.19 & 0.41 \\
\hline $\mathrm{CaO}$ & 0.120 & 0.096 & 0.066 & 0.058 & 0.061 & 0.017 \\
\hline $\mathrm{Fe}_{2} \mathrm{O}_{3}$ & 43.9 & 45.0 & 49.1 & 58.1 & 56.8 & 78.3 \\
\hline $\mathrm{K}_{2} \mathrm{O}$ & 0.29 & 0.52 & 0.57 & 1.63 & 2.10 & bdl \\
\hline $\mathrm{MgO}$ & 0.47 & 0.44 & 0.22 & 0.16 & 0.22 & 0.004 \\
\hline $\mathrm{MnO}$ & 0.036 & 0.035 & 0.019 & 0.015 & 0.019 & 0.001 \\
\hline $\mathrm{Na}_{2} \mathrm{O}$ & 0.013 & 0.019 & 0.014 & 0.026 & 0.18 & 0.19 \\
\hline \multirow[t]{2}{*}{$\mathrm{SO}_{3}$} & 12.9 & 12.3 & 11.5 & 11.5 & 10.2 & 0.56 \\
\hline & \multicolumn{5}{|c|}{ Trace elements $\left(\mathrm{mg} \mathrm{kg}^{-1}\right)$} & \\
\hline As & 258 & 213 & 197 & 222 & 224 & 632 \\
\hline Co & 4.31 & 3.26 & 2.75 & 4.10 & 3.32 & 0.49 \\
\hline $\mathrm{Cu}$ & 7940 & 5270 & 4130 & 6560 & 6540 & 191 \\
\hline $\mathrm{Ni}$ & 4.73 & 11.1 & 6.50 & 1.85 & 7.27 & 0.40 \\
\hline $\mathrm{Pb}$ & 53.1 & 114 & 92.1 & 282 & 412 & 708 \\
\hline $\mathrm{Se}$ & 3.09 & 1.79 & 3.78 & 2.73 & 3.08 & 4.69 \\
\hline $\mathrm{Ti}$ & 2.37 & 5.02 & 7.60 & 8.12 & 14.7 & 66.6 \\
\hline V & 16.6 & 7.16 & 16.7 & 17.8 & 15.5 & 201 \\
\hline $\mathrm{Zn}$ & 1121 & 1031 & 598 & 537 & 631 & 2.37 \\
\hline
\end{tabular}




\section{Table 2}

\begin{tabular}{|c|c|c|c|c|c|c|c|c|c|c|c|}
\hline depth $(\mu \mathrm{m})$ & 31-82 & $82-270$ & $270-285$ & $285-390$ & $390-410$ & $410-590$ & $590-620$ & $620-680$ & $680-715$ & $715-820$ & $820-940$ \\
\hline Mineralogy & Hem & $G t$ & Hem & $G t$ & Hem & $G t$ & Hem & $G t$ & Hem & $G t$ & Hem \\
\hline & \multicolumn{11}{|c|}{ Major elements (\%) } \\
\hline $\mathrm{SiO}_{2}$ & 0.91 & 1.00 & 1.02 & 1.07 & 0.93 & 1.03 & 1.00 & 0.85 & 0.93 & 0.80 & 0.94 \\
\hline $\mathrm{Al}_{2} \mathrm{O}_{3}$ & 0.39 & 2.15 & 0.22 & 0.47 & 0.16 & 0.84 & 0.35 & 0.95 & 0.10 & 0.83 & 0.17 \\
\hline $\mathrm{Fe}_{2} \mathrm{O}_{3}$ & 83.7 & 73.8 & 82.7 & 72.7 & 83.8 & 73.5 & 81.9 & 75.2 & 83.3 & 73.5 & 84.0 \\
\hline $\mathrm{CaO}$ & 0.02 & 0.03 & 0.04 & bdl & 0.01 & bdl & 0.01 & 0.03 & 0.03 & 0.02 & 0.05 \\
\hline $\mathrm{K}_{2} \mathrm{O}$ & 0.03 & 0.02 & 0.01 & 0.02 & 0.01 & 0.02 & 0.01 & 0.02 & 0.01 & 0.02 & 0.01 \\
\hline \multirow[t]{2}{*}{$\mathrm{SO}_{3}$} & 0.57 & 1.18 & 0.57 & 1.28 & 0.64 & 1.29 & 0.66 & 1.01 & 0.65 & 1.31 & 0.41 \\
\hline & \multicolumn{11}{|c|}{ Trace elements (mg kg-1) } \\
\hline As & 1692 & 2086 & 1884 & 2284 & 1917 & 4498 & 2653 & 4194 & 1754 & 3907 & 2608 \\
\hline $\mathrm{Cu}$ & bdl & 1678 & bdl & 987 & bdl & 1039 & bdl & 1923 & bdl & 899 & 959 \\
\hline $\mathrm{Pb}$ & 2409 & 928 & 2107 & 1105 & 2831 & 2228 & 2315 & 2234 & 1866 & 2027 & 2001 \\
\hline $\mathrm{Zn}$ & bdl & 964 & 152 & 550 & bdl & 402 & bdl & 801 & bdl & 1015 & bdl \\
\hline
\end{tabular}


Figure 1

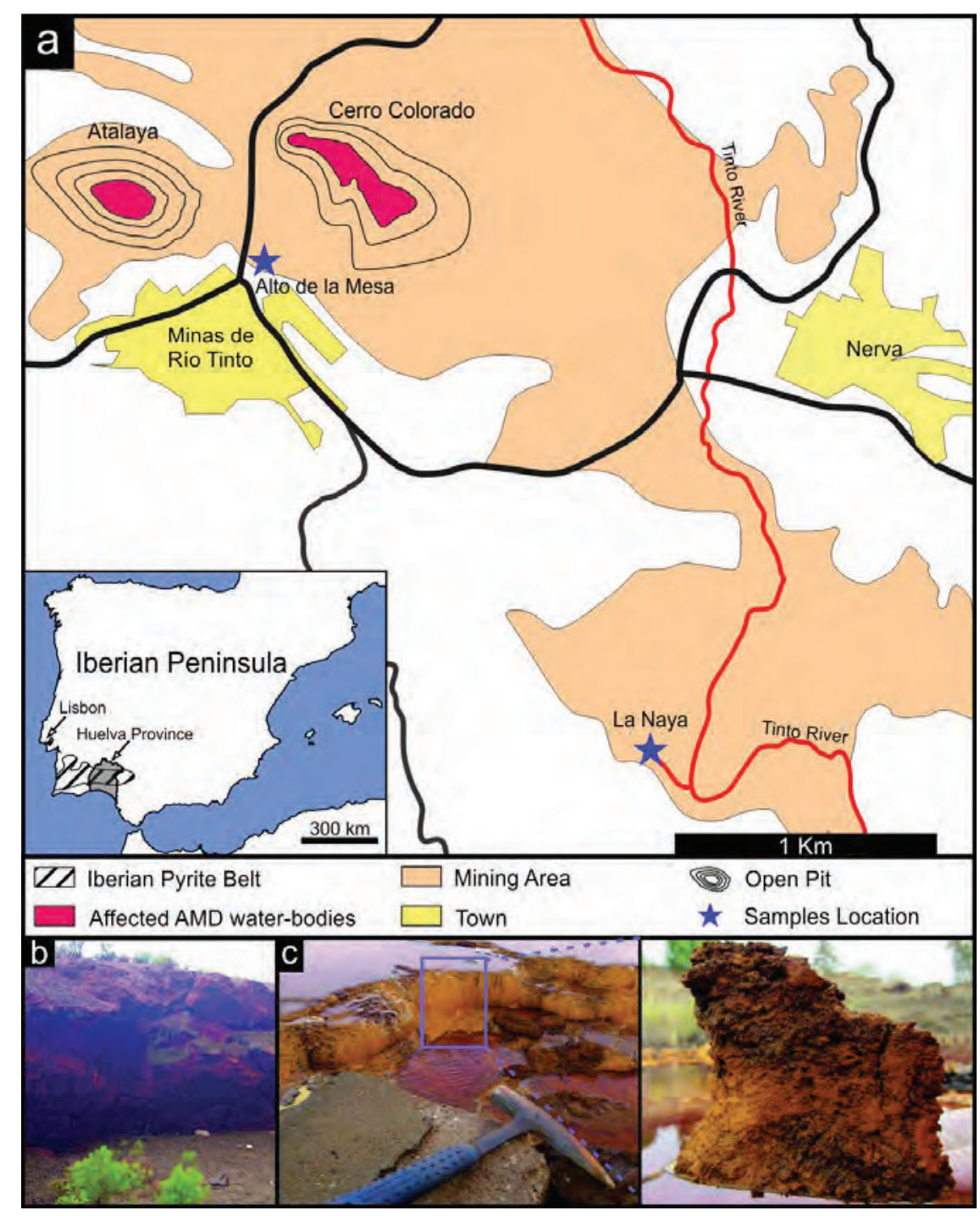


Figure 2

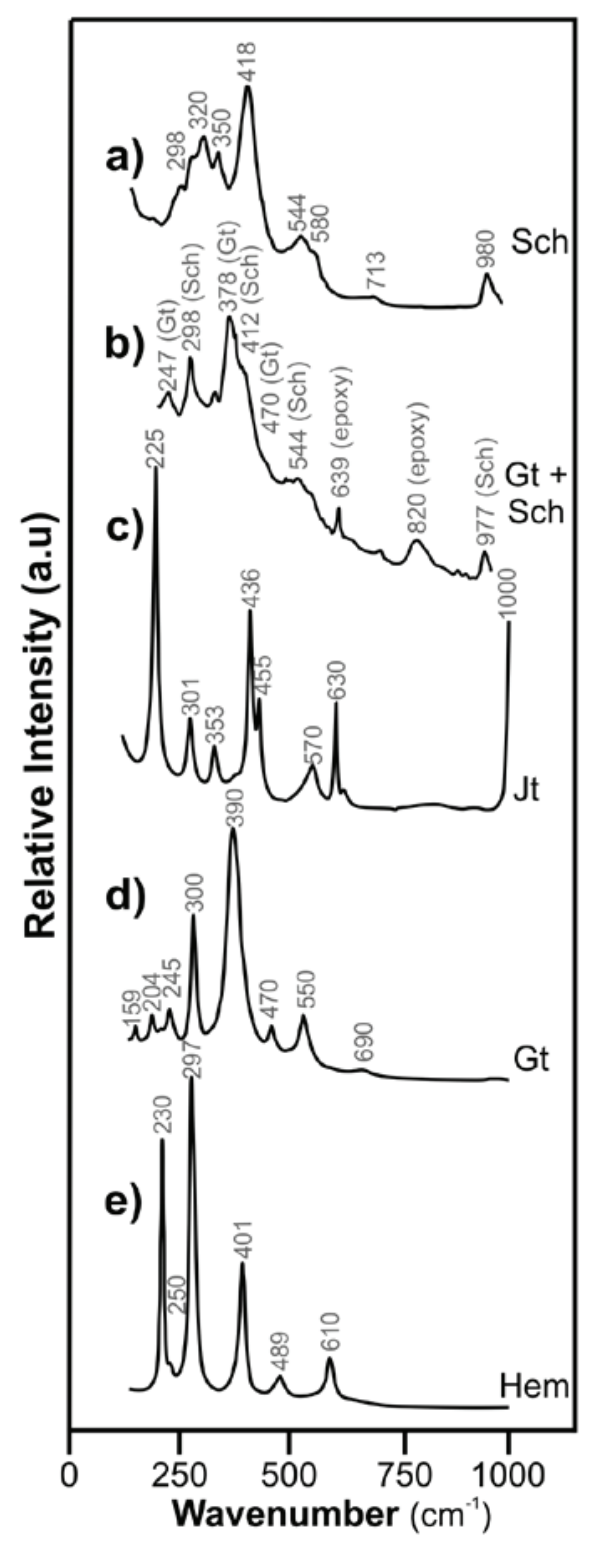


Figure 3
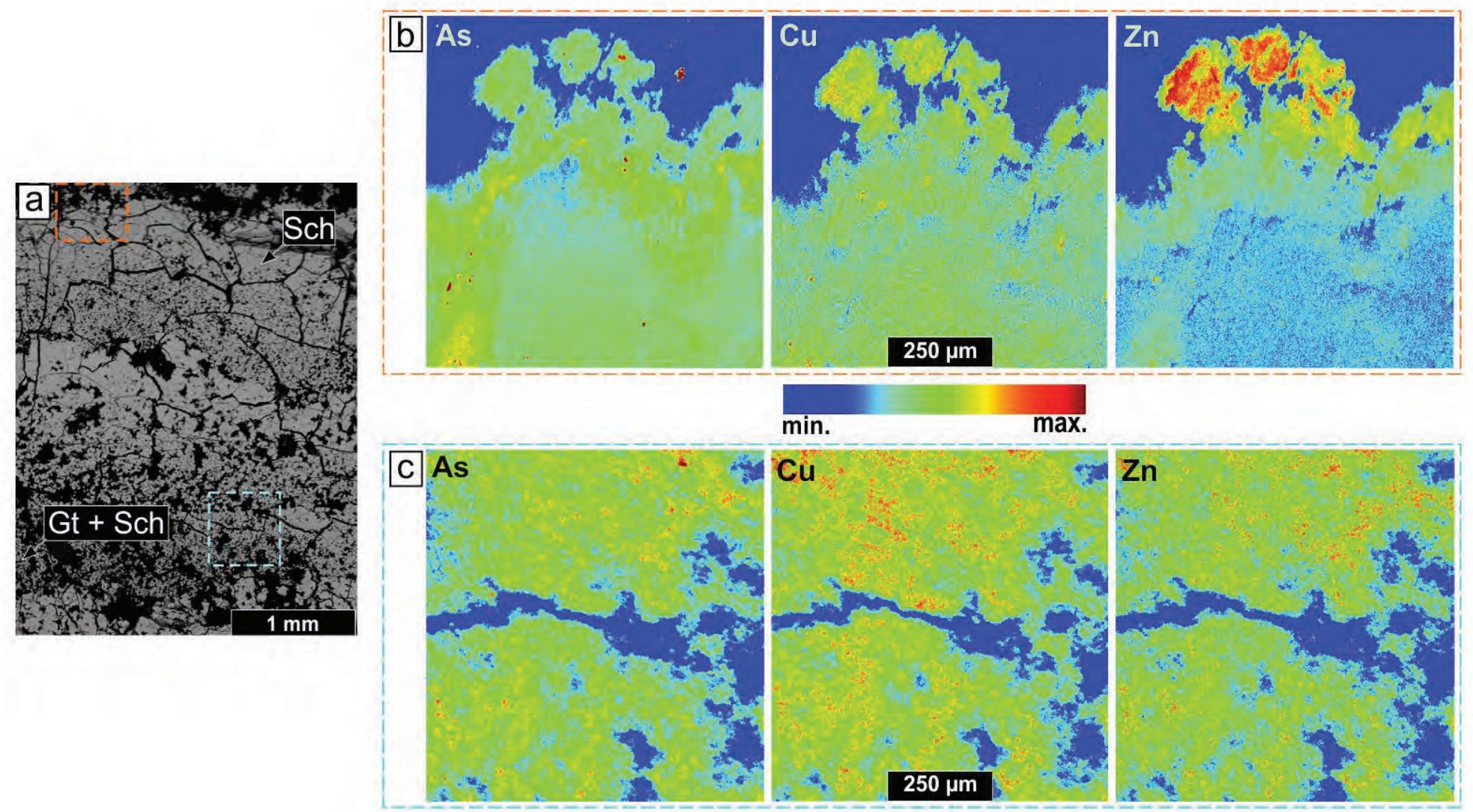
Figure 4
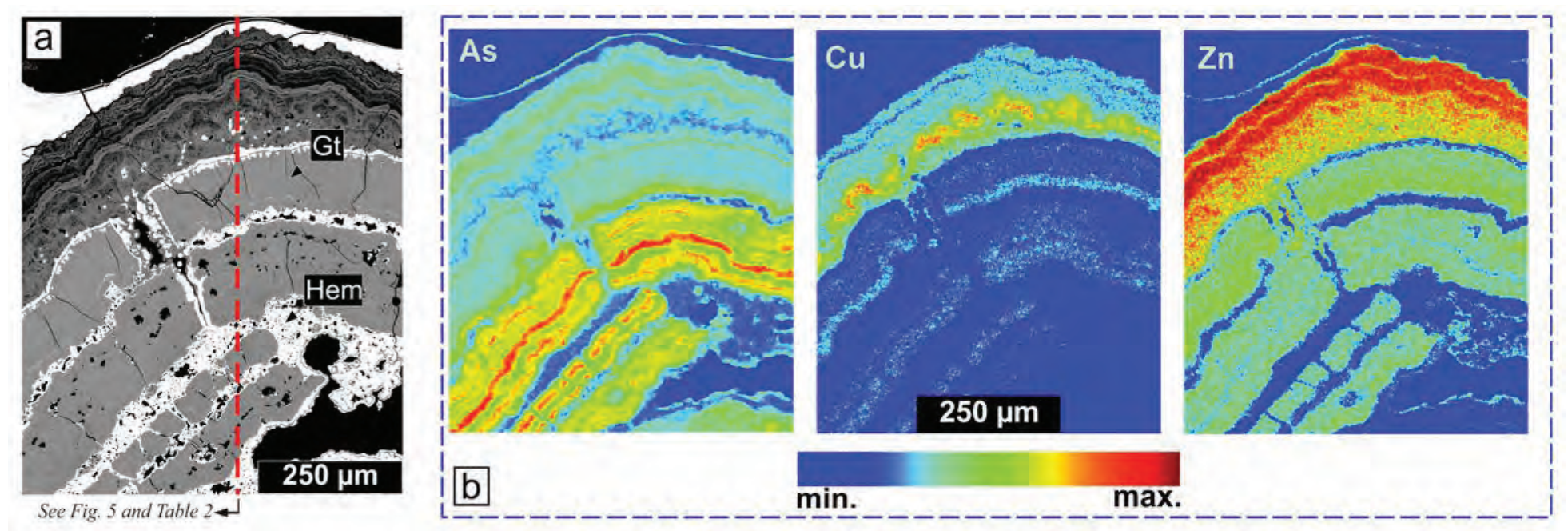


\section{Figure 5}

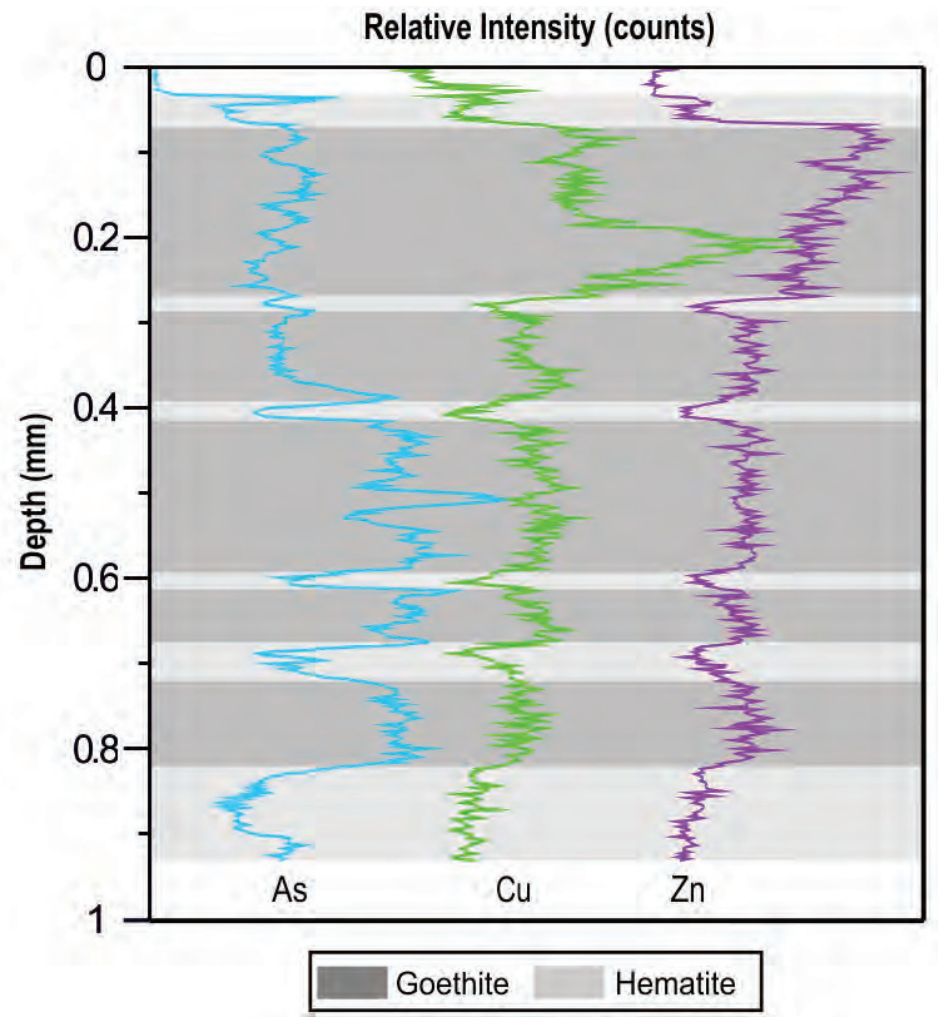




\section{Graphical Abstract}

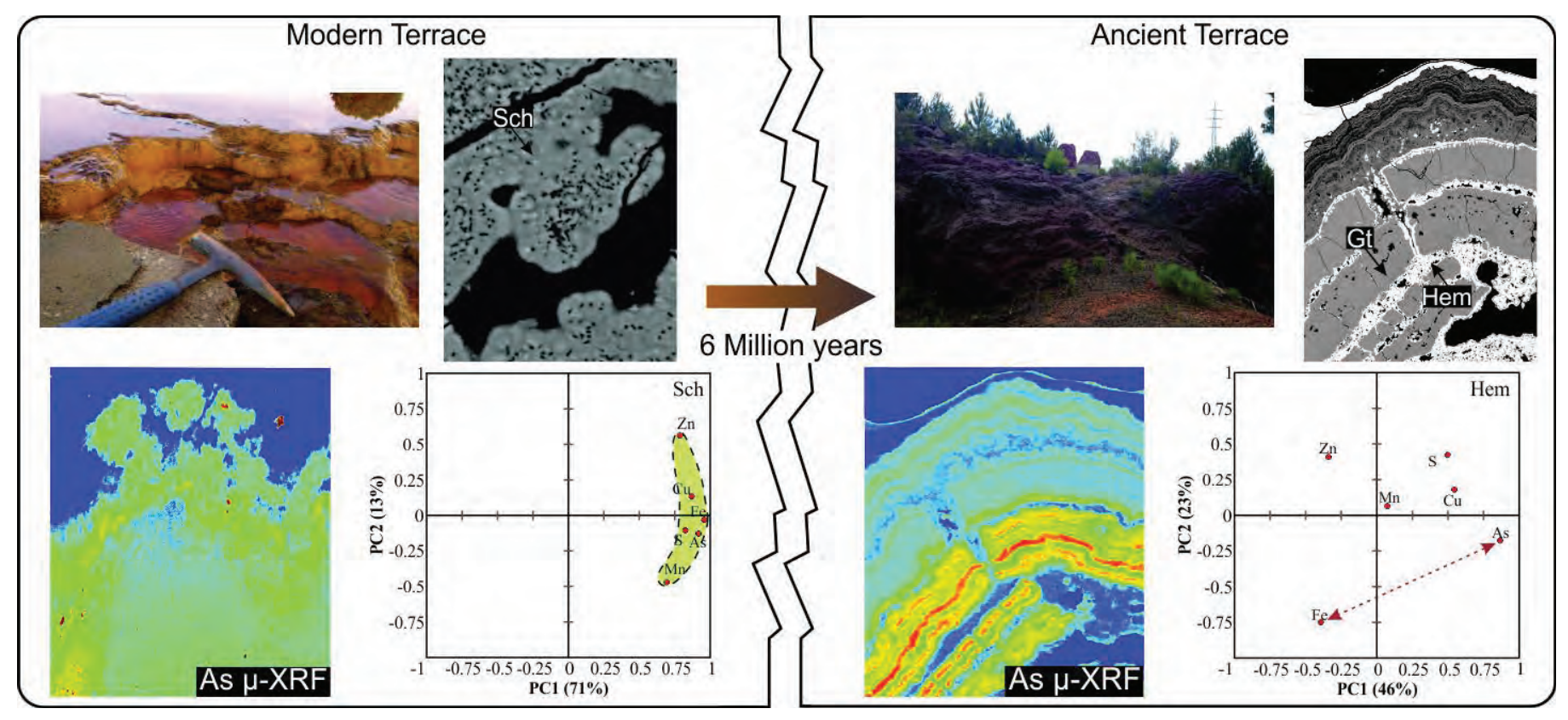

